OPEN ACCESS

Edited by:

Olivier Huck,

Université de Strasbourg, France

Reviewed by:

Nagihan Bostanci,

Karolinska Institutet (KI), Sweden

Kevimy Agossa,

Université de Lille, France

${ }^{*}$ Correspondence:

Oleh Andrukhov

oleh.andrukhov@meduniwien.ac.at

Specialty section: This article was submitted to

Oral Infections and Microbes, a section of the journal

Frontiers in Oral Health

Received: 02 January 2021 Accepted: 12 March 2021

Published: 16 April 2021

Citation:

Andrukhov O (2021) Toll-Like Receptors and Dental Mesenchymal

Stromal Cells

Front. Oral. Health 2:648901.

doi: 10.3389/froh.2021.648901

\section{Toll-Like Receptors and Dental Mesenchymal Stromal Cells}

\author{
Oleh Andrukhov* \\ Competence Center for Periodontal Research, University Clinic of Dentistry, Medical University of Vienna, Vienna, Austria
}

Dental mesenchymal stromal cells (MSCs) are a promising tool for clinical application in and beyond dentistry. These cells possess multilineage differentiation potential and immunomodulatory properties. Due to their localization in the oral cavity, these cells could sometimes be exposed to different bacteria and viruses. Dental MSCs express various Toll-like receptors (TLRs), and therefore, they can recognize different microorganisms. The engagement of TLRs in dental MSCs by various ligands might change their properties and function. The differentiation capacity of dental MSCs might be either inhibited or enhanced by TLRs ligands depending on their nature and concentrations. Activation of TLR signaling in dental MSCs induces the production of proinflammatory mediators. Additionally, TLR ligands alter the immunomodulatory ability of dental MSCs, but this aspect is still poorly explored. Understanding the role of TLR signaling in dental MSCs physiology is essential to assess their role in oral homeostasis, inflammatory diseases, and tissue regeneration.

Keywords: dental mesenchymal stromal cells, toll-like receptors, differentiation, immunomodulation, lipopolysaccharide

\section{TOLL-LIKE RECEPTORS}

Toll-like receptors (TLRs) are a family of proteins that play a key role in recognizing pathogens by the innate immune system $[1,2]$. TLRs are type I transmembrane proteins consisting of extracellular leucine-rich repeats (LRR) and intracellular toll/interleukin (IL)-1 receptor domains. To date, 10 different TLRs were described in humans. Some of them, particularly TLR-1, TLR-2, TLR-4, TLR-5, TLR-6, and TLR-10, are expressed on the cell surface, whereas TLR-3, TLR-7, TLR-8, and TLR-9 are present only in intracellular compartments such as lysosomes, endosomes, and endoplasmic reticulum [3].

Most TLRs function as homodimers, and only TLR-2 acts as a heterodimer with either TLR-1 or TLR-6 [4]. The crystal structure of the extracellular LRR domain is established for several TLRs [5]. This domain comprises 19-25 tandem LRR copies and contains hydrophobic residues spaced at specific intervals $[5,6]$. Various human TLRs differ in the number of LRR and domain structures, leading to recognizing different ligands [5]. Each TLR recognizes specific, highly conserved bacterial or viral structures. These structures are common for various pathogens and are crucial for their function. The most known TLR ligands are bacterial lipopeptides (TLR-2/TLR-1 and TLR-2/TLR-6), viral double-stranded RNA (TLR-3), lipopolysaccharide (TLR-4), bacterial flagellin (TLR-5), bacterial or viral single-stranded RNA (TLR-7 and TLR-8), and CpG-rich unmethylated DNA (TLR-9) [7]. The ligand and function of TLR-10 are poorly known [8]. It was shown that, in contrast to other TLRs, TLR-10 has an anti-inflammatory action and dampen TLR-2 response [9]. A recent study indicated that TLR-10 might sense HIV-1 envelope protein [10]. Besides exogenous ligands, TLRs might also be activated by 
endogenous ligands released from damaged tissue or dead cells [11]. Activation of TLRs by endogenous ligands has a crucial role in the regulation of local tissue homeostasis.

After ligand binding, the intracellular TIR domain recruits adaptor molecules, which initiate the response [2]. The following adaptors are described: myeloid differentiation primary response gene 88 (MyD88), TIR-domain-containing adaptor protein (TIRAP), TIR domain-containing adaptor inducing interferon$\beta$ (TRIF), and TRIF-related adaptor molecule (TRAM) [12]. Activation of almost all TLRs excepting TLR-3 results in triggering of MyD88- or MyD88/TIRAP-dependent response, leading to the activation of nuclear factor kappa B (NF-кB) and proinflammatory cytokine production. Ligand binding to TLR-3 activates the TRIF-dependent pathway and induces type I interferon (IFN) signaling. Finally, TLR-4 activates both NF$\kappa \mathrm{B}$ mediated by MyD88 and type I IFN pathway through TRAM/TRIF [3].

\section{DENTAL MESENCHYMAL STROMAL CELLS}

The International Society for Cell and Gene Therapy (ISCT) defines mesenchymal stromal cells (MSCs) as plastic-adherent fibroblast-like cells; expressing mesenchymal surface markers CD73, CD90, and CD105; lacking hematopoietic surface markers CD11b, CD14, CD34, CD45, and HLA-DR; and possessing the ability to differentiate into osteoblasts, adipocytes, and chondrocytes in vitro [13, 14]. For the first time, MSCs were isolated from the bone marrow, but later, MSCs were found in almost all postnatal tissues [15], including dental pulp [16], human exfoliated deciduous teeth [17], periodontal ligament [18], apical papilla [19], dental follicle [20], gingival tissue [21], and periapical cyst [22]. Most dental-tissue-derived MSCs also express several neural lineage markers, presumably due to their neural crest origin [23-25]. Sometimes, the abbreviation "MSCs" is used as an acronym for "mesenchymal stem cells." There is an ongoing discussion if these cells should be classified as "stromal" or "stem" cells mainly because of their limited differentiation ability in vivo and lacking asymmetric division $[26,27]$. In the present review, we will adhere to the recent recommendation of ISCT to use the term "mesenchymal stromal cells" in combination with tissue origin [14].

Despite the high plasticity of MSCs in vitro, the differentiation ability of transplanted MSCs in vivo is very limited [28]. Nowadays, there is a large consensus that the therapeutic effect of MSCs is achieved through either secretion of specific trophic factors or immunomodulatory function [29]. As reviewed by several papers, dental MSCs possess a strong immunomodulatory ability and can regulate the function of different immune cells [30-35]. The effects of dental MSCs are most often immunosuppressive and are mediated by the production of soluble factors and direct cell-to-cell contact [30]. The immunomodulatory capacity of dental MSCs is usually low and is boosted by different inflammatory cytokines like IFN$\gamma$, tumor necrosis factor (TNF)- $\alpha$, and interleukin (IL)- $1 \beta$. These cytokines are produced by the activated immune cells and upregulate the expression of different immunomodulatory factors in dental MSCs, e.g., indolamine-2,3-dioxygenase 1 (IDO-1), prostaglandin E2 (PGE2), TNF- $\alpha$-stimulated gene 6 (TSG-6), programmed cell death-ligand 1 (PD-L1), and PD-L2 [36-40]. Thus, it seems that dental MSCs and immune cells regulate each other's activity in a reciprocal manner, which can be implicated in various processes such as tissue regeneration and inflammatory disease progression [30].

According to ISCT criteria, the cell population can be defined as MSCs if more than $95 \%$ of the population expresses mesenchymal markers and $<2 \%$ of the population expresses hematopoietic markers. However, despite these strict criteria, MSCs usually represent rather heterogeneous than homogeneous cell population [41]. Considerable heterogeneity is observed even within single-cell-derived MSCs clones [42]. Besides MSCs themselves, cell populations might comprise osteoblasts, fibroblasts, and other cells of mesenchymal origin, which surface markers are indistinguishable from those of MSCs [43, 44]. It should be noted that fibroblasts-like cells were isolated from various human dental tissues, e.g., dental pulp (human dental pulp cells, hDPCs), gingiva (human gingival fibroblasts, hGFs), and periodontal ligament (human periodontal ligament cells, hPDLCs). These cells share many properties of the corresponding "stem cell" populations isolated from these tissues and express similar surface markers [45-47]. The present review will comprise the studies with both MSC-like cells and fibroblastlike cells from various dental tissues, and the cell names will be indicated as they are mentioned in the corresponding paper.

Toll-like receptors impact MSCs biology and affect their functions such as proliferation, migration, differentiation potential, immunomodulatory ability, and survival [48-50]. The oral cavity is a habitat for different microorganisms [51, 52]. Host-microbial homeostasis is a crucial determinant of oral health, and its disruption is associated with oral diseases, like caries and periodontitis [53]. Interaction of bacteria- and viralderived TLR ligands might affect the functional properties of dental MSCs and needs to be understood. This narrative review aims to summarize state-of-the-art on the role of TLRs and their ligands in dental MSCs.

\section{TLRs EXPRESSION IN DENTAL MSCs}

The expression of TLRs in different dental MSCs was investigated specifically rather rarely. However, the presence of some TLRs, like TLR-2, TLR-3, and TLR-4 in these cells is indisputable because of their responsiveness to the corresponding ligands [5456]. Some studies investigated specifically the expression and regulation of TLRs in various dental MSCs. Li et al. analyzed the expression of different TLRs in human periodontal ligament stem cells (hPDLSCs) and compared it with that in bone marrow MSCs [57]. They found that in comparison to BM-MSCs, hPDLSCs express significantly higher levels of TLR-1, TLR-2, and TLR-5, as well as significantly lower levels of TLR-3, TLR4, TLR-6, TLR-8, TLR-9, and TLR-10 [57]. Zhu et al. showed that hPDLSCs express TLR-1, TLR-2, TLR-3, TLR-4, and TLR6 on both gene and protein levels as shown by quantitative PCR 
(qPCR) and flow cytometry analysis, respectively [58]. El-Sayed et al. investigated the expression of TLRs in different dental MSCs population and its regulation by the inflammatory cytokine cocktails consisting of IL- $1 \beta$, IFN- $\alpha$, IFN- $\gamma$, and TNF- $\alpha[59,60]$. Human gingival MSCs (hGMSCs) were shown to express TLR-1, $2,3,4,5,6,7,10$ on the gene and protein levels [59]. Treatment of these cells with the inflammatory cocktail resulted in the downregulation of TLR-6 and upregulation of all other TLRs [59]. Resting human dental pulp stem cells (hDPSCs) were found to express all TLRs in different quantities [61]. Treatment of DPSCs with inflammatory cytokines induced upregulation of TLR-2, 3, 4, 5; downregulation of TLR-1, 7, 9, 10; and abolishment of TLR-6 [61]. MSCs derived from alveolar bone were found to express all TLRs except TLR-9 [60]. The highest expression levels were found for TLR-2 and the lowest one for TLR-6 [60]. Thus, there are some differences in the TLRs expression and regulation between dental MSCs of different origins, but their physiological importance for a particular specific tissue should still be established.

\section{EFFECT OF TLRs LIGANDS ON DIFFERENTIATION POTENTIAL OF DENTAL MSCs}

Numerous studies investigated the effect of TLR ligands on the differentiation potential of dental MSCs in vitro. The majority of them focused on the impact of lipopolysaccharide (LPS) on osteogenic differentiation, presumably because of the putative role of dental MSCs in alveolar bone regeneration. In these studies, osteogenic differentiation was assessed by the expression of specific markers like alkaline phosphatase (ALP), osteocalcin $(\mathrm{OCN})$, collagen 1 (Coll-1), osteopontin (OPN), osterix (OSX), and runt-related transcription factor 2 (RUNX-2) as well as by mineralization assay (alizarin red staining). LPS was used as an essential virulence factor of Gram-negative bacteria, which is involved in the etiology of periodontitis and pulpitis $[62,63]$.

In contrast to LPS, the effect of other bacterial components on the osteogenic differentiation of dental MSCs is investigated rarely. However, such studies would be especially important because both Gram-negative and Gram-positive bacteria continuously secrete numerous proteins, which might activate various TLRs and exert multiple cellular effects in MSCs. Particularly, lipoteichoic acid, peptidoglycan, and fimbriae activate TLR-2 [4, 64-66]; bacterial flagellin activates TLR-5 [67]. A microarray study showed that Porphyromonas gingivalis secreted products activated several signaling pathways involved in bone metabolism and inflammatory and immune response [68], and therefore, identifying the potential contribution of all TLRs in dental MSCs physiology would be very important [67].

\section{Periodontal-Ligament-Derived MSCs}

The effect of LPS on the osteogenic differentiation of periodontalligament-derived MSCs is investigated most extensively. Li et al. showed that Escherichia coli LPS $(10 \mu \mathrm{g} / \mathrm{ml})$ decreases osteogenic differentiation and RUNX-2 expression in human periodontal ligament stem cells (hPDLSCs) but not that of BMMSCs [57]. This effect was mediated through TLR-4 induced NF- $\kappa \mathrm{B}$ activation [57]. Kato et al. reported that $P$. gingivalis LPS $(1-10 \mu \mathrm{g} / \mathrm{ml})$ inhibits mineralization and expression of ALP, OCN, and Coll-1 by human hPDLSCs [69]. Wei et al. found that E. coli LPS $(10 \mu \mathrm{g} / \mathrm{ml})$ inhibits osteogenic differentiation, alkaline phosphatase expression and activity, and gene expression of OCN, Coll-1, and RUNX-2 in hPDLCs [70]. Kim et al. demonstrated that E. coli LPS $(2 \mu \mathrm{g} / \mathrm{ml})$ inhibits osteogenic differentiation of hPDLCs and the expression of BMP-2, OSX, and RUNX-2 [71]. Zhu et al. showed that E. coli LPS $(1-10 \mu \mathrm{g} / \mathrm{ml})$ inhibits ALP activity and mineralization of hPDLSCs, and this effect was partially reversed by MyD88 and TRIF silencing [58]. Wang et al. reported that E. coli LPS $(0.1-10 \mu \mathrm{g} / \mathrm{ml})$ inhibits osteogenic differentiation, ALP activity, and RUNX-2 expression of hPDLSCs through TLR-4 dependent mechanism [72]. Yu et al. showed that $P$. gingivalis LPS $(10 \mu \mathrm{g} / \mathrm{ml})$ inhibits the osteogenic differentiation of $h$ PDLSCs and decreases the expression of OCN, RUNX-2, and Coll-1 [73]. Blufstein et al. found that $P$. gingivalis LPS $(1 \mu \mathrm{g} / \mathrm{ml})$ in combination with soluble CD14 inhibits the basal and vitamin- $\mathrm{D}_{3}$-induced expression of $\mathrm{OCN}$ and $\mathrm{OPN}$ in hPDLCs [74].

Some studies did not confirm the inhibitory effect of LPS on the osteogenic differentiation of periodontal-ligament-derived MSCs. Jönsson et al. showed that E. coli LPS $(0.5-10 \mu \mathrm{g} / \mathrm{ml})$ does not affect Coll-1 production by hPDLCs [75]. Li et al. did not find any significant effect of E. coli LPS $(1 \mu \mathrm{g} / \mathrm{ml})$ on the osteogenic differentiation, ALP activity, gene and protein expression of ALP, RUNX-2, and Coll-1 by hPDLCs [76]. Albiero et al. did not observe any influence of $P$. gingivalis LPS $(1 \mu \mathrm{g} / \mathrm{ml})$ on the osteogenic potential of hPDLSCs [77]. Jia et al. reported that $P$. gingivalis LPS $(10 \mu \mathrm{g} / \mathrm{ml})$ does not affect the expression of ALP, Coll-1, RUNX-2, OCN, OPN, and OSX in hPDLCs but inhibits it when the cyclic stress was applied to the cells [78].

Some studies reported the stimulatory effect of LPS on osteogenic differentiation. Albeiro et al. showed that E. coli LPS $(1 \mu \mathrm{g} / \mathrm{ml})$ stimulates osteogenic differentiation as well as the expression of ALP, OCN, and RUNX-2 [79]. Xing et al. observed that E. coli LPS $(0.5 \mu \mathrm{g} / \mathrm{ml})$ stimulates osteogenic differentiation, ALP activity, and the expression of ALP, RUNX-2, OCN, and Coll-1 presumably through $\mathrm{Wnt} / \beta$-catenin-dependent mechanism [80]. Thus, it seems that the effect of LPS on the osteogenic differentiation of periodontal-ligament-derived MSCs depends on the concentration and, to a lesser extent, on LPS source. High LPS concentrations inhibit osteogenic differentiation, whereas low LPS concentrations have no effect or even stimulate it.

Only two studies addressed the effect of other TLRs ligands on the osteogenic potential of periodontal-ligament-derived MSCs. Zhu et al. found that TLR-2/1 ligand Pam3CSK4 and TLR-2/6 ligand FSL-1 inhibit mineralization and ALP activity of hPDLSCs in a concentration-dependent manner, and this effect was partially reversed after MyD-88 knockdown [58]. TLR-3 ligand Poly I:C enhanced osteogenic differentiation and ALP activity at low concentration $(0.1 \mu \mathrm{g} / \mathrm{ml})$ and inhibited these parameters at higher concentration $(10 \mu \mathrm{g} / \mathrm{ml})$ [58]. Blufstein et al. showed that 
both basal and vitamin- $\mathrm{D}_{3}$-induced expression of OCN and OPN are inhibited by TLR-2/1 ligand Pam3CSK4 [74].

Besides participating in alveolar bone metabolism, periodontal-ligament-derived MSCs participate in the cementogenesis [81]. Kim et al. showed that E. coli LPS $(2 \mu \mathrm{g} / \mathrm{ml})$ inhibited the expression of CEMP-1, which is involved in cementogenesis [71].

\section{Dental-Pulp-Derived MSCs}

Some contradictory data are reported regarding the effect of LPS on osteogenic differentiation of dental-pulp-derived MSCs. Yamagishi et al. found that $P$. gingivalis LPS $(5-20 \mu \mathrm{g} / \mathrm{ml})$ induces a dose-dependent inhibition of OCN expression in hDPSCs [82]. Yuan et al. showed that E. coli LPS $(10 \mu \mathrm{g} / \mathrm{ml})$ inhibits the mineralization and expression of ALP, OCN, OPN, OSX, and RUNX-2 in rat dental pulp stem cells [83]. In contrast, Huang et al. reported a dose-dependent increase in ALP activity and mineralization of human dental pulp cells (hDPCs) by $E$. coli LPS (0.1-10) [84]. He et al. found that the stimulatory effect of E. coli LPS $(1 \mu \mathrm{g} / \mathrm{ml})$ on mineralization of hDPSCs and expression of ALP and OCN is mediated by TLR- 4 activation [85]. Chung et al. demonstrated that $P$. gingivalis LPS $(1 \mu \mathrm{g} / \mathrm{ml})$ in combination with soluble CD14 stimulates the expression of OCN and mineralization of hDPSCs [86]. Wildbiller et al. did not observe any significant effect of $E$. coli LPS $(0.01-1 \mu \mathrm{g} / \mathrm{ml})$ on the expression of OCN and Coll-1 in hDPSCs [87].

Besides common trilineage differentiation potential, dentalpulp-derived MSCs can differentiate into odontoblast and assumed to participate in dentin regeneration [88]. The effect of TLR ligands on the odontogenic differentiation of dental-pulpderived MSCs is differently discussed in the literature. Yamagishi et al. reported that the expression of dentin sialophosphoprotein (DSPP) in hDPSCs is inhibited by $P$. gingivalis LPS $(5-20 \mu \mathrm{g} / \mathrm{ml})$ in a concentration-dependent manner [82]. Wildbiller et al. showed that $E$. coli LPS $(0.01-1 \mu \mathrm{g} / \mathrm{ml})$ suppress the expression of DSPP and dentin matrix protein 1 (DMP-1) in hDPSCs induced by extracted dentine matrix proteins but does not affect their basal expression [87]. Huang et al. found that E. coli LPS $(0.1-10 \mu \mathrm{g} / \mathrm{ml})$ enhances the expression of DSPP and DMP-1 in hDPCs in a dose-dependent manner [84]. He et al. showed that E. coli LPS induces DSPP and DMP-1 in hDPSCs through the mitogen-activated protein kinase signaling pathway [85]. Finally, the exosomes from LPS preconditioned DPSCs promoted proliferation, migration, and odontogenic differentiation of Schwann cells [89].

\section{Apical Papilla and Dental-Follicle-Derived MSCs}

Apical-papilla-derived MSCs (stem cells from apical papilla, SCAP) reside in the apical papilla of permanent teeth. They possess osteogenic, adipogenic, chondrogenic, neurogenic, and odontogenic differentiation potential [90]. Lei et al. found that $P$. gingivalis LPS $(5 \mu \mathrm{g} / \mathrm{ml})$ inhibited mineralization and expression of ALP, RUNX-2, and DMP-1 in SCAP by inducing autophagy [91]. Kukreti et al. showed that the culture of SCAP on Pseudomonas aeruginosa-coated dentin strongly inhibits mineralization and expression of DSPP and DMP-1 [92].
Human dental follicle stem cells (hDFSCs) are isolated from follicle tissue surrounding the tooth germ [20, 93]. Morsczeck et al. found that E. coli LPS $(1 \mu \mathrm{g} / \mathrm{ml})$ and $P$. gingivalis LPS $(1 \mu \mathrm{g} / \mathrm{ml})$ stimulates ALP activity but inhibits the mineralization of human hDFSCs [94]. The effect of E. coli LPS was more pronounced than that of $P$. gingivalis LPS [94].

\section{Gingiva-Derived MSCs}

Gingiva-derived MSCs are unique MSCs that possess multilineage differentiation potential and are considered to be promising cells for oral tissue regeneration [95]. Karlis et al. showed that TLR-2/1 ligand Pam2CSK4, ultrapure $P$. gingivalis LPS, and standard $P$. gingivalis LPS (all $0.01 \mu \mathrm{g} / \mathrm{ml}$ ) do not affect the mineralization (calcium deposition) and the expression of ALP and osteonectin in chronically stimulated human GFs [96]. The same study found that GFs chronically stimulated with TLR-2 and TLR-4 ligands slightly attenuate osteoclastogenesis activity in coculture experiments [96].

\section{TLR LIGANDS AND THE IMMUNOREGULATORY ROLE OF DENTAL MSCs}

MSCs produce a plethora of various factors involved in regulating the inflammatory response [97]. The production of these factors is usually upregulated by inflammatory cytokines and TLRs ligands [48, 97]. One group of these factors includes proinflammatory cytokine and chemokines like IL-1 $\beta$, TNF- $\alpha$, IL-6, IL-8, MCP-1, etc. These proteins usually have a proinflammatory action, promote immune cell migration, and induced tissue destruction. The second group of factors comprises different immunosuppressive proteins like IDO-1, PGE2, TSG-6, PD-L1, PD-L2, and TGF- $\beta$. These proteins have immunosuppressive anti-inflammatory effects related to "immunomodulatory properties of MSCs" [30, 98]. Activation of MSCs with TLR ligands usually activates both proinflammatory and anti-inflammatory responses, and the balance between them depends on the type and concentration of TLR ligand [49].

\section{The Proinflammatory Response of Dental MSCs to TLR-4 Ligand Lipopolysaccharide}

LPS is a cell wall component of Gram-negative bacteria and is a well-known TRL-4 ligand [99]. Numerous studies dealt with the effect of different LPS preparations on the production of various proinflammatory factors by dental MSCs. In these studies, MSC-like cells from various dental tissues were with LPS at concentrations ranging from 0.01 to $50 \mu \mathrm{g} / \mathrm{ml}$. The resulting production of various proinflammatory factors was detected [e.g., $[100,101]]$. For the sake of clearness and due to space limitation reasons, only some critical aspects of LPS-induced response in dental MSCs will be mentioned without the detailed overview of all existing data.

LPS is recognized by TLR-4 in complex with MD-2. The binding of LPS to the TLR-4/MD-2 complex is facilitated by lipopolysaccharide-binding protein and CD14 [102, 103]. The binding of LPS to CD14 enhances the sensitivity of 
host cells to endotoxin and enables sensing it even at picomolar concentrations [104]. Besides, CD14 is required for the internalization of TLR-4 and activation of TRIF-dependent signaling [105]. Membrane-bound CD14 (mCD14) is a GPIanchored protein, which is expressed by various immune cells [106]. However, MSCs, by definition, do not express mCD14 on their surface [13]. Besides the membrane-bound form, there is also a soluble form of CD14 (sCD14) [107]. Our group showed that sCD14 increases the sensitivity and amplitude of hPDLSCs to $P$. gingivalis LPS and E. coli LPS [100]. sCD14 is present in serum, saliva, and gingival crevicular fluid, and therefore, it might be implicated in dental MSCs response to LPS in in vivo situations [108-110]. However, the majority of studies on the effect of LPS on dental MSCs does not use sCD14.

An increase in the production of IL-6, IL-8, and MCP-1 by periodontal-ligament-derived MSCs is most often reported $[69,75,100,111-113]$. Some studies also reported that LPS increases the production of IL- $1 \beta$ and TNF- $\alpha$ by periodontalligament-derived MSCs [70, 71, 79], whereas one study did not confirm this finding [113]. Additionally, a stimulatory effect of LPS on the expression of IL-12, intercellular adhesion molecule 1, vascular adhesion molecule 1, and macrophage colonystimulating factor is described [71, 113, 114]. The responsiveness of periodontal-ligament-derived MSCs to LPS might be modified by the inflammatory environment. Early studies suggest that hPDLCs are unresponsive to LPS from E. coli and Aggregatibacter actinomycetemcomitans $(0.1 \mu \mathrm{g} / \mathrm{ml})$ [115]. Pretreatment with a low concentration of IL- $1 \beta$ induced the responsibility of these cells to both LPS [115]. LPS-primed hPDLSCs were shown to promote macrophage polarization toward a proinflammatory M1 phenotype [116].

In gingiva-derived MSCs, bacterial LPS induced the production of IL-6, IL-8, and MCP-1 [117-120]. The data on the production of IL- $1 \beta$ and TNF- $\alpha$ by hGFs upon LPS stimulation are contradictory: it is supported by some studies $[121,122]$ and denied by other studies [123, 124]. Additionally, GFs produced CCL5 [125], macrophage inflammatory protein3 upon stimulation with LPS [126]. Pretreatment of hGFs with IFN- $\gamma$ enhanced the expression of CD14, TLR-2, and TLR-4; induced surface expression of CD14; and increased responsiveness to LPS stimulation [127].

Several studies investigated the proinflammatory response of other dental-derived MSCs to bacterial LPS. Porphyromonas gingivalis LPS induced IL-6 and IL- 8 and inhibited TGF- $\beta$ production by hDPSCs [86]. In hDPCs, $E$. coli LPS enhanced the gene expression of IL-6, IL-1 $\beta$, and TNF- $\alpha$ [128]. Stimulation of SCAP with LPS resulted in the upregulation of IL-6, IL-8, IL$1 \beta$, and TNF- $\alpha[129,130]$. In DFSCs, both E. coli LPS and $P$. gingivalis LPS induced the production of IL-6, IL-8, and MCP1, and the effect of $E$. coli LPS was markedly higher than that of $P$. gingivalis LPS [94]. In another study on dental follicle progenitor cells, $P$. gingivalis LPS could not induce IL-6 production but changed the expression of TLR- 2 and TLR- 4 and stimulated cell migration [131].

It should be noted that several factors could influence the response of dental MSCs to LPS. Our recent study showed that LPS purity is an essential factor influencing the response of hPDLSCs and hGMSCs to bacterial LPS
[119]. Commercially available LPS preparations are usually contaminated by lipoproteins (about 2\%). When LPS is applied at a concentration of $50 \mu \mathrm{g} / \mathrm{ml}$, the concentrations of contaminating lipoproteins might reach $1 \mu \mathrm{g} / \mathrm{ml}$. At this concentration, lipoproteins can induce a robust inflammatory response $[66,132]$, and therefore, it is difficult to discriminate if the response originates from LPS or lipoproteins. Contaminating lipoproteins also account for the ability of some $P$. gingivalis LPS preparation to activate TLR-2 response $[119,133]$. Stimulation time is another factor influencing the response to LPS. For example, Widbiller et al. showed that $E$. coli LPS does not affect IL-6 production by hDPSCs after a short time (1 day) but increases it after 4-7 days [87].

\section{The Proinflammatory Response of Dental MSCs to Other TLR Ligands}

The effect of TLR-2 and TLR-3 ligands on the production of proinflammatory cytokines by dental MSCs is investigated relatively rarely. Some studies of our group showed that TLR2/1 ligand Pam3CSK4, TLR-2 ligand lipoteichonic acid (LTA), and TLR-3 ligand Poly I:C induce the production of IL-6, IL8 , and MCP- 1 by hPDLSCs by a much greater extent than LPS $[56,66,100,134]$. The response of hPDLSCs to TLR-2 ligands is enhanced by sCD14 [66], which is not surprising because CD14 serves as an assessor molecule for TLR-2 [103]. Pam3CSK4, Poly $\mathrm{I}: \mathrm{C}$, and TLR-2/6 ligand FSL- 1 activated NF-kB and increased the gene expression of IL- 6 , IL- 8 , TNF- $\alpha$, and IL- $1 \beta$ in hPDLSCs [58]. In GFs, Poly I:C, FSL-1, TLR-7/8 ligand ssPolyU, and TLR9 ligand CpG DNA significantly induced the production of IL6, IL-8, and MCP-1 [135]. In contrast, another study on hGFs showed that IL- 8 production was enhanced by LPS, Poly I:C, and TLR-5 ligand flagellin but not by TLR-7, 8, and 9 ligands [136]. Different bacterial LTA and Pam3CSK4 induced IL-6 and IL-8 production in hGFs $[137,138]$. TLR-2-primed hGFs stimulated the proliferation of $\mathrm{CD}^{+}$-positive T cells [139].

\section{Immunomodulatory Activity of TLR-Primed Dental MSCs}

The role of different TLRs in the immunomodulatory ability of MSCs in general is still not entirely understood. Earlier studies suggested that the priming of MSCs with TLR-2- or TLR-4-primed MSCs stimulate the immune response, whereas TLR-3-primed MSCs exhibit immunosuppressive properties $[49,140]$. However, some studies challenged this conception [141, 142]. Thus, the immunomodulatory role of different TLRs in MSC-mediated immunomodulation still needs to be investigated. Unfortunately, there are only a limited number of studies in which the effects of different TLR ligands on the immunomodulatory activity of dental MSCs are investigated.

Tomic et al. found that TLR-3 ligand poly I:C enhanced the inhibitory effect of MSCs derived from dental pulp and dental follicle on peripheral blood mononuclear cells (PBMCs) proliferation [143]. However, TLR-4 ligand LPS augmented immunosuppression only in dental follicle MSCs and abrogated it in dental pulp MSCs [143]. The anti-TGF- $\beta$ antibody strongly abrogated the immunosuppressive effect of both cell types. Moreover, the effect of TLR ligands on TGF- $\beta$ expression showed a similar pattern as for immunosuppressive properties. 


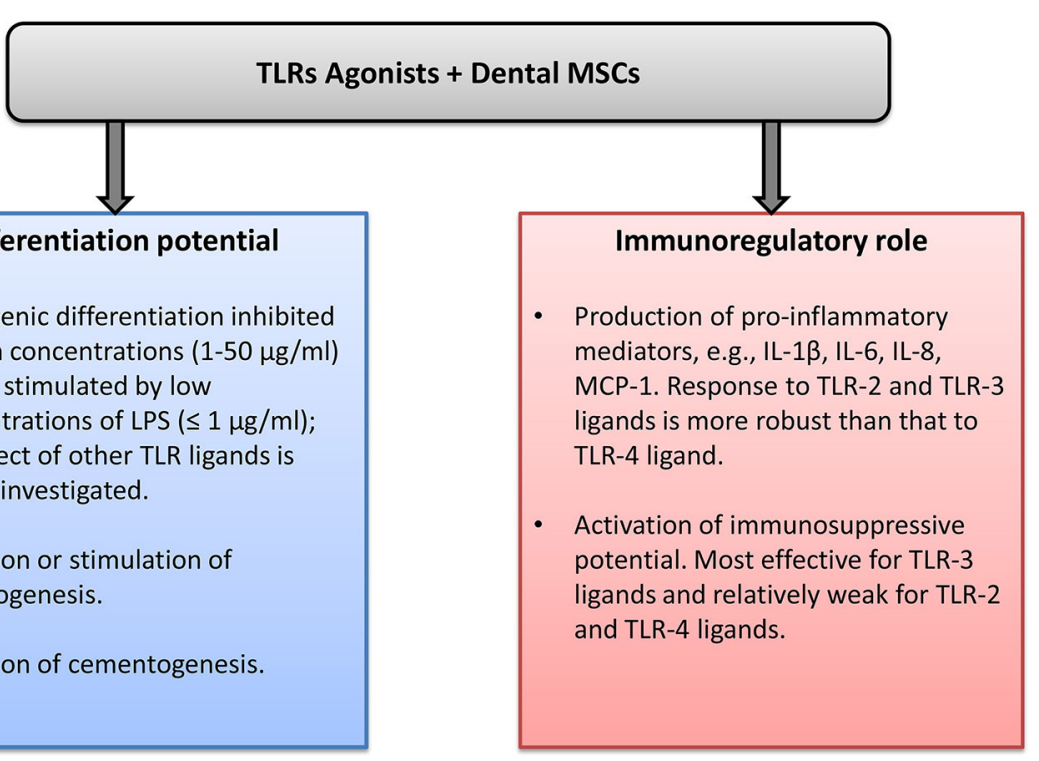

FIGURE 1 | Effects of toll-like receptor (TLR) agonists in dental mesenchymal stromal cells (MSCs).

Similarly, TLR-3 ligand enhanced TGF- $\beta$ production in both MSCs types, whereas TLR-4 ligand LPS enhanced TGF$\beta$ production in dental follicle MSCs and inhibited it in dental pulp MSCs. Priming hPDLSCs with LPS decreased the frequency of $\mathrm{CD}_{3} 3^{+}$and $\mathrm{CD}_{1}{ }^{+}$myeloid cells within the PBMCs population but did not affect their immunosuppressive activity on $\mathrm{T}$ cell proliferation and differentiation [112]. GFs pretreated with $P$. gingivalis-derived LPS stimulated the ability of the GFs to suppress PBMCs proliferation and enhanced the IFN- $\gamma$-induced immunosuppressive ability [136]. However, the immunomodulatory effect of $P$. gingivalis LPS was relatively small compared with that of IFN- $\gamma$ [136].

TLR ligands were shown to affect the expression of some immunomodulatory proteins in dental MSCs. MSCmediated immunosuppression in humans is largely mediated by indoleamine-2,3-dioxygenase-1 (IDO-1), which catalyzes the catabolism of L-tryptophan into L-kynurenine [144], and the resulting depletion of tryptophan leads to the immunosuppression [145]. The majority of existing reports suggest that TLR ligands enhance IDO-1 gene expression in dental MSCs. The enhanced IDO-1 gene expression was induced in hPDLs by E. coli LPS [146]; in hPDLSCs by Pam3CSK4 and Poly I:C [147, 148]; in hDPSCs by E. coli LPS [149]; in hGFs by $P$. gingivalis LPS, E. coli LPS, and flagellin [40, 136]; and in hGMSCs by Poly I:C [150]. No stimulatory effect on IDO1 gene expression was observed in hPDLSCs upon E. coli LPS stimulation [147] and in hGMSCs upon stimulation with TLR-1, $2,4,6$, and 7 ligands [150]. In contrast to the gene expression data, the effect of various TLRs ligands on IDO-1 protein expression and enzymatic activity in dental MSCs is somewhat controversial. Intracellular IDO-1 expression was not affected by Pam3CSK4 and E. coli LPS in hPDLSCs [147], by P. gingivalis and E. coli LPS in hDPSCs and hDFSCs [143], and PamsCSK4 and E. coli LPS in hDPSCs [39]. In contrast, IDO-1 protein expression was enhanced in hPDLSCs by Poly I:C and in hDPSCs by E. coli LPS [149]. The enzymatic activity of IDO-1 in conditioned media was reported to be increased by Pam3CSK4 and Poly I:C in hPDLSCs [148] and by E. coli LPS in hPDLs [146]. In contrast, no effect of $P$. gingivalis LPS on IDO-1 activity was observed in GFs [40]. Several studies reported that IDO-1 expression and activity induced by TLR-3 ligand Poly I:C is substantially higher than those induced by other TLR ligands [147, 149, 150]. This observation suggests a superior role of TLR-3 signaling in the immunomodulatory properties of dental MSCs, which should be confirmed by future functional studies.

\section{CONCLUDING REMARKS AND FUTURE PERSPECTIVE}

Resident dental MSCs are involved in both inflammatory response and dental tissue repair after trauma. The clinical protocols for applying dental MSCs for the treatment of periodontal and endodontic defects are currently developing [151-153]. Besides, due to their accessibility and functional properties, dental MSCs have an enormous potential for application beyond the dental field [23]. Numerous preclinical researches imply an enormous perspective of dental MSCs for the application in bone and cartilage repair and the treatment of immunological disorders [30, 154, 155]. The mechanisms underlying in vivo regenerative potential are based mainly on modifying the environment [30, 156]. Furthermore, the exosomes of dental MSCs are considered to be a promising tool for the regeneration of oral and extraoral tissues $[157,158]$.

Dental MSCs express all human TLRs, and the effects of TLRs ligand in dental MSCs are summarized in Figure 1. The differentiation capacity of dental MSCs can be either diminished or enhanced by various TLR ligands. This effect might depend 
on the concentration and type of TLR ligand. Stimulation of dental MSCs with different TLR ligands induces the production of various proinflammatory mediators, mainly IL-6, IL-8, and MCP-1. This fact suggests that dental MSCs might play an important role in the progression of different inflammatory diseases. However, the exact role of dental MSCs in oral diseases such as pulpitis and periodontitis is still to be clarified. The role of TLRs in the immunomodulation by dental MSCs is investigated rather poorly to date. Some reports suggest that TLRprimed MSCs promote immune response, whereas other reports indicate an immunosuppressive effect of TLR-treated dental MSCs. Future well-designed studies are necessary to clarify the role of TLRs in the immunomodulatory ability of dental MSCs. Understanding the role of MSCs in the inflammatory processes could open new perspectives for dental tissue regeneration and treatment of the inflammatory diseases.

\section{REFERENCES}

1. Medzhitov R. Toll-like receptors and innate immunity. Nat Rev Immunol. (2001) 1:135-45. doi: 10.1038/35100529

2. Akira S, Takeda K. Toll-like receptor signaling. Nat Rev Immunol. (2004) 4:499-511. doi: 10.1038/nri1391

3. Kawasaki T, Kawai T. Toll-like receptor signaling pathways. Front Immunol. (2014) 5:461. doi: 10.3389/fimmu.2014.00461

4. Oliveira-Nascimento L, Massari P, Wetzler LM. The role of TLR2 in infection and immunity. Front Immunol. (2012) 3:79. doi: 10.3389/fimmu.2012.00079

5. Botos I, Segal DM, Davies DR. The structural biology of toll-like receptors. Structure. (2011) 19:447-59. doi: 10.1016/j.str.2011.02.004

6. Bell JK, Mullen GE, Leifer CA, Mazzoni A, Davies DR, Segal DM. Leucinerich repeats and pathogen recognition in toll-like receptors Trends Immunol. (2003) 24:528-33. doi: 10.1016/S1471-4906(03)00242-4

7. Kumar H, Kawai T, Akira S. Pathogen recognition in the innate immune response. Biochem J. (2009) 420:1-16. doi: 10.1042/BJ20090272

8. Fore F, Indriputri C, Mamutse J, Nugraha J. TLR10 and its unique antiinflammatory properties and potential use as a target in therapeutics. Immune Netw. (2020) 20:e21. doi: 10.4110/in.2020.20.e21

9. Oosting M, Cheng SC, Bolscher JM, Vestering-Stenger R, Plantinga TS, Verschueren IC, et al. Human TLR10 is an anti-inflammatory pattern-recognition receptor. Proc Natl Acad Sci USA. (2014) 111:E447884. doi: 10.1073/pnas.1410293111

10. Henrick BM, Yao XD, Zahoor MA, Abimiku A, Osawe S, Rosenthal KL. TLR10 senses HIV-1 proteins and significantly enhances HIV-1 infection. Front Immunol. (2019) 10:482. doi: 10.3389/fimmu.2019.00482

11. $\mathrm{Yu} \mathrm{L,} \mathrm{Wang} \mathrm{L,} \mathrm{Chen} \mathrm{S.} \mathrm{Endogenous} \mathrm{toll-like} \mathrm{receptor} \mathrm{ligands}$ and their biological significance. J Cell Mol Med. (2010) 14:2592-603. doi: 10.1111/j.1582-4934.2010.01127.x

12. Kawai T, Akira S. The role of pattern-recognition receptors in innate immunity: update on toll-like receptors. Nat Immunol. (2010) 11:37384. doi: $10.1038 /$ ni. 1863

13. Dominici M, Le Blanc K, Mueller I, Slaper-Cortenbach I, Marini F, Krause $D$, et al. Minimal criteria for defining multipotent mesenchymal stromal cells. The International Society for Cellular Therapy position statement. Cytotherapy. (2006) 8:315-7. doi: 10.1080/14653240600855905

14. Viswanathan S, Shi Y, Galipeau J, Krampera M, Leblanc K, Martin I, et al. Mesenchymal stem versus stromal cells: International Society for Cell and Gene Therapy (ISCT(R)) Mesenchymal Stromal Cell committee position statement on nomenclature. Cytotherapy. (2019) 21:1019-24. doi: 10.1016/j.jcyt.2019.08.002

15. Chamberlain G, Fox J, Ashton B, Middleton J. Concise review: mesenchymal stem cells: their phenotype, differentiation capacity, immunological features, and potential for homing. Stem Cells. (2007) 25:2739-49. doi: 10.1634/stemcells.2007-0197

\section{AUTHOR CONTRIBUTIONS}

OA created the concept and wrote the manuscript.

\section{FUNDING}

This work was supported by Austrian Science Fund (FWF), Project P29440.

\section{ACKNOWLEDGMENTS}

The author is thankful to the whole Research Group of Competence Center for Periodontal Research, University Clinic of Dentistry, Medical University of Vienna for their endless support.

16. Gronthos S, Mankani M, Brahim J, Robey PG, Shi S. Postnatal human dental pulp stem cells (DPSCs) in vitro and in vivo. Proc Natl Acad Sci USA. (2000) 97:13625-30. doi: 10.1073/pnas.240309797

17. Miura M, Gronthos S, Zhao M, Lu B, Fisher LW, Robey PG, et al. SHED: stem cells from human exfoliated deciduous teeth. Proc Natl Acad Sci USA. (2003) 100:5807-12. doi: 10.1073/pnas.0937635100

18. Seo BM, Miura M, Gronthos S, Bartold PM, Batouli S, Brahim J, et al. Investigation of multipotent postnatal stem cells from human periodontal ligament. Lancet. (2004) 364:149-55. doi: 10.1016/S0140-6736(04)16627-0

19. Sonoyama W, Liu Y, Yamaza T, Tuan RS, Wang S, Shi S, et al. Characterization of the apical papilla and its residing stem cells from human immature permanent teeth: a pilot study. J Endod. (2008) 34:16671. doi: 10.1016/j.joen.2007.11.021

20. Morsczeck C, Gotz W, Schierholz J, Zeilhofer F, Kuhn U, Mohl C, et al. Isolation of precursor cells (PCs) from human dental follicle of wisdom teeth. Matrix Biol. (2005) 24:155-65. doi: 10.1016/j.matbio.2004.12.004

21. Zhang Q, Shi S, Liu Y, Uyanne J, Shi Y, Shi S, et al. Mesenchymal stem cells derived from human gingiva are capable of immunomodulatory functions and ameliorate inflammation-related tissue destruction in experimental colitis. J Immunol. (2009) 183:7787-98. doi: 10.4049/jimmunol.0902318

22. Marrelli M, Paduano F, Tatullo M. Cells isolated from human periapical cysts express mesenchymal stem cell-like properties. Int J Biol Sci. (2013) 9:1070-8. doi: 10.7150/ijbs.6662

23. Sharpe PT. Dental mesenchymal stem cells. Development. (2016) 143:227380. doi: 10.1242/dev.134189

24. Bakopoulou A, About I.. Stem Cells of dental origin: current research trends and key milestones towards clinical application. Stem Cells Int. (2016) 2016:4209891. doi: 10.1155/2016/4209891

25. Widera D, Grimm WD, Moebius JM, Mikenberg I, Piechaczek C, Gassmann $\mathrm{G}$, et al. Highly efficient neural differentiation of human somatic stem cells, isolated by minimally invasive periodontal surgery. Stem Cells Dev. (2007) 16:447-60. doi: 10.1089/scd.2006.0068

26. Robey P. "Mesenchymal stem cells": fact or fiction, and implications in their therapeutic use. F1000Res. (2017) 6:F1000. doi: 10.12688/f1000research.10955.1

27. Sipp D, Robey PG, Turner L. Clear up this stem-cell mess. Nature. (2018) 561:455-7. doi: 10.1038/d41586-018-06756-9

28. Pittenger MF, Discher D, Péault BM, Phinney DG, Hare JM, Caplan AI, et al. Mesenchymal stem cell perspective: cell biology to clinical progress. $n p j$ Regenerative Med. (2019) 4:22. doi: 10.1038/s41536-019-0083-6

29. Spees JL, Lee RH, Gregory C. Mechanisms of mesenchymal stem/stromal cell function. Stem Cell Res Ther. (2016) 7:125. doi: 10.1186/s13287-016-0363-7

30. Andrukhov O, Behm C, Blufstein A, Rausch-Fan X. Immunomodulatory properties of dental tissue-derived mesenchymal stem cells: implication in disease and tissue regeneration. World J Stem Cells. (2019) 11:60417. doi: $10.4252 /$ wjsc.v11.i9.604 
31. Li Z, Jiang CM, An S, Cheng Q, Huang YF, Wang YT, et al. Immunomodulatory properties of dental tissue-derived mesenchymal stem cells. Oral Dis. (2014) 20:25-34. doi: 10.1111/odi.12086

32. Zhou LL, Liu W, Wu YM, Sun WL, Dorfer CE, Fawzy El-Sayed KM. Oral mesenchymal stem/progenitor cells: the immunomodulatory masters. Stem Cells Int. (2020) 2020:1327405. doi: 10.1155/2020/1327405

33. Wada N, Gronthos S, Bartold PM. Immunomodulatory effects of stem cells. Periodontol 2000. (2013) 63:198-216. doi: 10.1111/prd.12024

34. Racz GZ, Kadar K, Foldes A, Kallo K, Perczel-Kovach K, Keremi B, et al. Immunomodulatory and potential therapeutic role of mesenchymal stem cells in periodontitis. J Physiol Pharmacol. (2014) 65:327-39.

35. Trubiani O, Pizzicannella J, Caputi S, Marchisio M, Mazzon E, Paganelli $\mathrm{R}$, et al. Periodontal ligament stem cells: current knowledge and future perspectives. Stem Cells Dev. (2019) 28:995-1003. doi: 10.1089/scd.2019.0025

36. Behm C, Blufstein A, Gahn J, Kubin B, Moritz A, Rausch-Fan X, et al. Pleiotropic effects of vitamin D3 on CD4(+) T lymphocytes mediated by human periodontal ligament cells and inflammatory environment. J Clin Periodontol. (2020) 47:689-701. doi: 10.1111/jcpe.13283

37. Behm C, Blufstein A, Gahn J, Nemec M, Moritz A, Rausch-Fan $\mathrm{X}$, et al. Cytokines differently define the immunomodulation of mesenchymal stem cells from the periodontal ligament. Cells. (2020) 9:1222. doi: 10.3390/cells 9051222

38. Wada N, Menicanin D, Shi S, Bartold PM, Gronthos S. Immunomodulatory properties of human periodontal ligament stem cells. J Cell Physiol. (2009) 219:667-76. doi: $10.1002 / j c p .21710$

39. Takegawa D, Nakanishi T, Hirao K, Yumoto H, Takahashi K, Matsuo T. Modulatory roles of interferon-gamma through indoleamine 2, 3dioxygenase induction in innate immune response of dental pulp cells. $J$ Endod. (2014) 40:1382-7. doi: 10.1016/j.joen.2014.03.018

40. Nisapakultorn K, Makrudthong J, Sa-Ard-Iam N, Rerkyen P, Mahanonda R, Takikawa O. Indoleamine 2,3-dioxygenase expression and regulation in chronic periodontitis. J Periodontol. (2009) 80:114-21. doi: 10.1902/jop.2009.080315

41. Wilson A, Hodgson-Garms M, Frith JE, Genever P. Multiplicity of mesenchymal stromal cells: finding the right route to therapy. Front Immunol. (2019) 10:1112. doi: 10.3389/fimmu.2019.01112

42. McLeod CM, Mauck RL. On the origin and impact of mesenchymal stem cell heterogeneity: new insights and emerging tools for single cell analysis. Eur Cell Mater. (2017) 34:217-31. doi: 10.22203/eCM.v034a14

43. Denu RA, Nemcek S, Bloom DD, Goodrich AD, Kim J, Mosher DF, et al. Fibroblasts and mesenchymal stromal/stem cells are phenotypically indistinguishable. Acta Haematol. (2016) 136:85-97. doi: 10.1159/0004 45096

44. Ugurlu B, Karaoz E. Comparison of similar cells: mesenchymal stromal cells and fibroblasts. Acta Histochem. (2020) 122:151634. doi: 10.1016/j.acthis.2020.151634

45. Tatullo M, Marrelli M, Shakesheff KM, White LJ. Dental pulp stem cells: function, isolation and applications in regenerative medicine. J Tissue Eng Regen Med. (2015) 9:1205-16. doi: 10.1002/term.1899

46. Silverio KG, Rodrigues TL, Coletta RD, Benevides L, Da Silva JS, Casati $\mathrm{MZ}$, et al. Mesenchymal stem cell properties of periodontal ligament cells from deciduous and permanent teeth. J Periodontol. (2010) 81:120715. doi: 10.1902/jop.2010.090729

47. Du L, Pishan Y, Ge S. (2016). Isolation and characterization of human gingiva-derived mesenchymal stem cells using limiting dilution method. $J$ Dental Sci. 11:304-14. doi: 10.1016/j.jds.2016.03.010

48. Najar M, Krayem M, Meuleman N, Bron D, Lagneaux L. Mesenchymal stromal cells and toll-like receptor priming: a critical review. Immune Netw. (2017) 17:89-102. doi: 10.4110/in.2017.17.2.89

49. Delarosa O, Dalemans W, Lombardo E. Toll-like receptors as modulators of mesenchymal stem cells. Front Immunol. (2012) 3:182. doi: $10.3389 /$ fimmu.2012.00182

50. Shirjang S, Mansoori B, Solali S, Hagh MF, Shamsasenjan K. Toll-like receptors as a key regulator of mesenchymal stem cell function: an up-to-date review. Cell Immunol. (2017) 315:1-10. doi: 10.1016/j.cellimm.2016.12.005

51. Devine DA, Marsh PD, Meade J. Modulation of host responses by oral commensal bacteria. J Oral Microbiol. (2015) 7:26941. doi: 10.3402/jom.v7.26941
52. Olsen I, Lambris JD, Hajishengallis G. Porphyromonas gingivalis disturbs host-commensal homeostasis by changing complement function. $J$ Oral Microbiol. (2017) 9:1340085. doi: 10.1080/20002297.2017.1340085

53. Rosier BT, Marsh PD, Mira A. Resilience of the oral microbiota in health: mechanisms that prevent dysbiosis. J Dent Res. (2018) 97:37180. doi: $10.1177 / 0022034517742139$

54. Jia L, Han N, Du J, Guo L, Luo Z, Liu Y. Pathogenesis of important virulence factors of porphyromonas gingivalis via toll-like receptors. Front Cell Infect Microbiol. (2019) 9:262. doi: 10.3389/fcimb.2019.00262

55. Nilsson BO. Mechanisms involved in regulation of periodontal ligament cell production of pro-inflammatory cytokines: implications in periodontitis. $J$ Periodontal Res. (2021) 56:249-55. doi: 10.1111/jre.12823

56. Blufstein A, Behm C, Gahn J, Uitz O, Naumovska I, Moritz A, Rausch-Fan X, et al. Synergistic effects triggered by simultaneous toll-like receptor- 2 and -3 activation in human periodontal ligament stem cells. J Periodontol. (2019) 90:1190-201. doi: 10.1002/JPER.19-0005

57. Li C, Bei L, Zhiwei D, Li G, Xiaoning H, Li L, et al. Lipopolysaccharide differentially affects the osteogenic differentiation of periodontal ligament stem cells and bone marrow mesenchymal stem cells through toll-like receptor 4 mediated nuclear factor $\mathrm{\kappa B}$ pathway. Stem Cell Res Ther. (2014) 5:67. doi: $10.1186 /$ scrt 456

58. Zhu Y, Qian L, Yanheng Z, Weiran L. TLR activation inhibits the osteogenic potential of human periodontal ligament stem cells through Akt signaling in a Myd88- or TRIF-dependent manner. J Periodontol. (2018) 90:40015. doi: 10.1002/JPER.18-0251

59. Fawzy-El-Sayed K, Mekhemar M, Adam-Klages S, Kabelitz D, Dorfer C. TlR expression profile of human gingival margin-derived stem progenitor cells. Med Oral Patol Oral Cir Bucal. (2016) 21:e30-8. doi: 10.4317/medoral.20593

60. Fawzy El-Sayed KM, Boeckler J, Dorfer CE. TLR expression profile of human alveolar bone proper-derived stem/progenitor cells and osteoblasts. $J$ Craniomaxillofac Surg. (2017) 45:2054-60. doi: 10.1016/j.jcms.2017.09.007

61. Fawzy El-Sayed KM, Klingebiel P, Dorfer CE. Toll-like receptor expression profile of human dental pulp stem/progenitor cells. J Endod. (2016) 42:4137. doi: 10.1016/j.joen.2015.11.014

62. Jain S, Darveau RP. Contribution of Porphyromonas gingivalis lipopolysaccharide to periodontitis. Periodontol 2000. (2010) 54:53-70. doi: 10.1111/j.1600-0757.2009.00333.x

63. Chung MK, Lee J, Duraes G, Ro JY. Lipopolysaccharide-induced pulpitis up-regulates TRPV1 in trigeminal ganglia. J Dent Res. (2011) 90:11037. doi: $10.1177 / 0022034511413284$

64. Hajishengallis G, Tapping RI, Harokopakis E, Nishiyama S, Ratti P, Schifferle RE, et al. Differential interactions of fimbriae and lipopolysaccharide from Porphyromonas gingivalis with the toll-like receptor 2-centred pattern recognition apparatus. Cell Microbiol. (2006) 8:1557-70. doi: 10.1111/j.1462-5822.2006.00730.x

65. Dziarski R, Gupta D. Staphylococcus aureus peptidoglycan is a tolllike receptor 2 activator: a reevaluation. Infect Immun. (2005) 73:52126. doi: 10.1128/IAI.73.8.5212-5216.2005

66. Behm C, Blufstein A, Gahn J, Noroozkhan N, Moritz A, Rausch-Fan $\mathrm{X}$, et al. Soluble CD14 enhances the response of periodontal ligament stem cells to toll-like receptor 2 agonists. Mediators Inflamm. (2019) 2019:8127301. doi: 10.1155/2019/8127301

67. Yoon SI, Kurnasov O, Natarajan V, Hong M, Gudkov AV, Osterman AL, et al. Structural basis of TLR5-flagellin recognition and signaling. Science. (2012) 335:859-64. doi: 10.1126/science.1215584

68. Reddi D, Belibasakis GN. Transcriptional profiling of bone marrow stromal cells in response to Porphyromonas gingivalis secreted products. PLoS ONE. (2012) 7:e43899. doi: 10.1371/journal.pone.0043899

69. Kato H, Taguchi Y, Tominaga K, Umeda M, Tanaka A. Porphyromonas gingivalis LPS inhibits osteoblastic differentiation and promotes pro-inflammatory cytokine production in human periodontal ligament stem cells. Arch Oral Biol. (2014) 59:16775. doi: 10.1016/j.archoralbio.2013.11.008

70. Wei L, Jiang Y, Zhou W, Liu S, Liu Y, Rausch-Fan X, et al. Strontium ion attenuates lipopolysaccharide-stimulated proinflammatory cytokine expression and lipopolysaccharide-inhibited early osteogenic differentiation of human periodontal ligament cells. J Periodontal Res. (2018) 53:9991008. doi: $10.1111 /$ jre. 12599 
71. Kim JE, Takanche JS, Yun BS, Yi HK. Anti-inflammatory character of Phelligridin D modulates periodontal regeneration in lipopolysaccharideinduced human periodontal ligament cells J Periodontal Res. (2018) 53:81624. doi: 10.1111/jre.12570

72. Wang W, Yuan C, Geng T, Liu Y, Zhu S, Zhang C, et al. Lipopolysaccharide inhibits osteogenic differentiation of periodontal ligament stem cells partially through toll-like receptor 4-mediated ephrinB2 downregulation. Clin Oral Investig. (2020) 24:3407-16. doi: 10.1007/s00784-020-03211-w

73. Yu B, Li Q, Zhou M. LPSinduced upregulation of the TLR4 signaling pathway inhibits osteogenic differentiation of human periodontal ligament stem cells under inflammatory conditions. Int J Mol Med. (2019) 43:234151. doi: 10.3892/ijmm.2019.4165

74. Blufstein A, Behm C, Kubin B, Gahn J, Moritz A, Rausch-Fan X, et al. Transcriptional activity of vitamin $\mathrm{D}$ receptor in human periodontal ligament cells is diminished under inflammatory conditions. J Periodontol. (2021) 92:137-48. doi: 10.1002/JPER.19-0541

75. Jönsson D, Nebel D, Bratthall G, Nilsson B-O. LPS-induced MCP-1 and IL-6 production is not reversed by oestrogen in human periodontal ligament cells. Arch Oral Biol. (2008) 53:896-902. doi: 10.1016/j.archoralbio.2008.05.001

76. Li L, Jiang H, Chen R, Zhou J, Xiao Y, Zhang Y, et al. Human $\beta$-defensin 3 gene modification promotes the osteogenic differentiation of human periodontal ligament cells and bone repair in periodontitis. Int J Oral Sci. (2020) 12:13. doi: 10.1038/s41368-020-0078-6

77. Albiero ML, Amorim BR, Casati MZ, Sallum EA, Nociti Junior FH, Silverio KG. Osteogenic potential of periodontal ligament stem cells are unaffected after exposure to lipopolysaccharides. Braz Oral Res. (2017) 31:ARTN.e17. doi: 10.1590/1807-3107bor-2017.vol31.0017

78. Jia R, Yi Y, Liu J, Pei D, Hu B, Hao H, et al. Cyclic compression emerged dual effects on the osteogenic and osteoclastic status of LPS-induced inflammatory human periodontal ligament cells according to loading force. BMC Oral Health. (2020) 20:7. doi: 10.1186/s12903-019-0987-y

79. Albiero ML, Amorim BR, Martins L, Casati MZ, Sallum EA, Nociti FH, Jr., et al. Exposure of periodontal ligament progenitor cells to lipopolysaccharide from Escherichia coli changes osteoblast differentiation pattern. J Appl Oral Sci. (2015) 23:145-52. doi: 10.1590/1678-775720140334

80. Xing Y, Zhang Y, Jia L, Xu X. Lipopolysaccharide from Escherichia coli stimulates osteogenic differentiation of human periodontal ligament stem cells through Wnt/ $\beta$-catenin-induced TAZ elevation. Mol Oral Microbiol. (2019) 34. doi: 10.1111/omi.12249

81. Zhu W, Liang M. Periodontal ligament stem cells: current status, concerns, and future prospects. Stem Cells Int. (2015) 2015:972313. doi: 10.1155/2015/972313

82. Yamagishi VT, Torneck CD, Friedman S, Huang GT, Glogauer M. Blockade of TLR2 inhibits Porphyromonas gingivalis suppression of mineralized matrix formation by human dental pulp stem cells. J Endod. (2011) 37:8128. doi: 10.1016/j.joen.2011.03.013

83. Yuan $\mathrm{H}$, Zhao $\mathrm{H}$, Wang J, Zhang $\mathrm{H}$, Hong L, Li H, et al. MicroRNA let-7c-5p promotes osteogenic differentiation of dental pulp stem cells by inhibiting lipopolysaccharide-induced inflammation via HMGA2/PI3K/Akt signal blockade. Clin Exp Pharmacol Physiol. (2019) 46:389-97. doi: 10.1111/1440-1681.13059

84. Huang Y, Jiang H, Gong Q, Li X, Ling J. Lipopolysaccharide stimulation improves the odontoblastic differentiation of human dental pulp cells. Mol Med Rep. (2015) 11:3547-52. doi: 10.3892/mmr.2014.3120

85. He W, Wang Z, Luo Z, Yu Q, Jiang Y, Zhang Y, et al. LPS promote the odontoblastic differentiation of human dental pulp stem cells via MAPK signaling pathway. J Cell Physiol. (2015) 230:554-61. doi: 10.1002/jcp.24732

86. Chung M, Lee S, Chen D, Kim U, Kim Y, Kim S, et al. Effects of different calcium silicate cements on the inflammatory response and odontogenic differentiation of lipopolysaccharide-stimulated human dental pulp stem cells. Materials (Basel). (2019) 12:1259. doi: 10.3390/ma12 081259

87. Widbiller M, Eidt A, Wolflick M, Lindner SR, Schweikl H, Hiller KA, et al. Interactive effects of LPS and dentine matrix proteins on human dental pulp stem cells. Int Endod J. (2018) 51:877-88. doi: 10.1111/iej.12897

88. Ledesma-Martinez E, Mendoza-Nunez VM, Santiago-Osorio E. Mesenchymal stem cells derived from dental pulp: a review. Stem Cells Int. (2016) 2016:4709572. doi: 10.1155/2016/4709572
89. Li J, Ju Y, Liu S, Fu Y, Zhao S. Exosomes derived from lipopolysaccharidepreconditioned human dental pulp stem cells regulate Schwann cell migration and differentiation. Connect Tissue Res. (2019). doi: 10.1080/03008207.2019.1694010. [Epub ahead of print].

90. Kang J, Fan W, Deng Q, He H, Huang F. Stem cells from the apical papilla: a promising source for stem cell-based therapy. Biomed Res Int. (2019) 2019:6104738. doi: 10.1155/2019/6104738

91. Lei S, Liu XM, Liu Y, Bi J, Zhu S, Chen X. Lipopolysaccharide downregulates the osteo-/odontogenic differentiation of stem cells from apical papilla by inducing autophagy. J Endod. (2020) 46:502-8. doi: 10.1016/j.joen.2020.01.009

92. Kukreti H, Li FC, Singh K, Sodhi R, Kishen A. Efficacy of bioactive nanoparticles on tissue-endotoxin induced suppression of stem cell viability, migration and differentiation. Int Endod J. (2020) 53:85970. doi: $10.1111 /$ iej.13283

93. Honda MJ, Imaizumi M, Tsuchiya S, Morsczeck C. Dental follicle stem cells and tissue engineering. J Oral Sci. (2010) 52:541-52. doi: 10.2334/josnusd.52.541

94. Morsczeck CO, Drees J, Gosau M. Lipopolysaccharide from Escherichia coli but not from Porphyromonas gingivalis induce pro-inflammatory cytokines and alkaline phosphatase in dental follicle cells Arch Oral Biol. (2012) 57:1595-601. doi: 10.1016/j.archoralbio.2012.07.016

95. Fawzy El-Sayed KM, Dörfer CE. Gingival mesenchymal stem/progenitor cells: a unique tissue engineering gem. Stem Cells Int. (2016) 2016:116. doi: 10.1155/2016/7154327

96. Karlis GD, Schöningh E, Jansen IDC, Schoenmaker T, Hogervorst JMA, van Veen HA, et al. Chronic exposure of gingival fibroblasts to TLR2 or TLR4 agonist inhibits osteoclastogenesis but does not affect osteogenesis. Front Immunol. (2020) 11:1693. doi: 10.3389/fimmu.2020.01693

97. Kyurkchiev D, Bochev I, Ivanova-Todorova E, Mourdjeva M, Oreshkova T, Belemezova $\mathrm{K}$, et al. Secretion of immunoregulatory cytokines by mesenchymal stem cells. World J Stem Cells. (2014) 6:552-70. doi: 10.4252/wjsc.v6.i5.552

98. Weiss ARR, Dahlke MH. Immunomodulation by mesenchymal stem cells (MSCs): mechanisms of action of living, apoptotic, and dead MSCs. Front Immunol. (2019) 10:1191. doi: 10.3389/fimmu.2019.01191

99. Lien E, Means TK, Heine H, Yoshimura A, Kusumoto S, Fukase K, et al. Toll-like receptor 4 imparts ligand-specific recognition of bacterial lipopolysaccharide. J Clin Invest. (2000) 105:497-504. doi: 10.1172/JCI8541

100. Andrukhov O, Andrukhova O, Ozdemir B, Haririan H, Muller-Kern M, Moritz A, et al. Soluble CD14 enhances the response of periodontal ligament stem cells to P. gingivalis lipopolysaccharide. PLoS ONE. (2016) 11:e0160848. doi: 10.1371/journal.pone.0160848

101. Jung IH, Lee DE, Yun JH, Cho AR, Kim CS, You YJ, et al. Antiinflammatory effect of (-)-epigallocatechin-3-gallate on Porphyromonas gingivalis lipopolysaccharide-stimulated fibroblasts and stem cells derived from human periodontal ligament. J Periodontal Implant Sci. (2012) 42:18595. doi: 10.5051/jpis.2012.42.6.185

102. Ryu JK, Kim SJ, Rah SH, Kang JI, Jung HE, Lee D, et al. Reconstruction of LPS transfer cascade reveals structural determinants within LBP, CD14, and TLR4-MD2 for efficient LPS recognition and transfer. Immunity. (2017) 46:38-50. doi: 10.1016/j.immuni.2016.11.007

103. Lee CC, Avalos AM, Ploegh HL. Accessory molecules for tolllike receptors and their function. Nat Rev Immunol. (2012) 12:168-79. doi: 10.1038/nri3151

104. Gioannini TL, Teghanemt A, Zhang D, Coussens NP, Dockstader W, Ramaswamy S, et al. Isolation of an endotoxin-MD-2 complex that produces toll-like receptor 4-dependent cell activation at picomolar concentrations. Proc Natl Acad Sci USA. (2004) 101:4186-91. doi: 10.1073/pnas.0306906101

105. Zanoni I, Ostuni R, Marek LR, Barresi S, Barbalat R, Barton GM, et al. CD14 controls the LPS-induced endocytosis of toll-like receptor 4. Cell. (2011) 147:868-80. doi: 10.1016/j.cell.2011.09.051

106. Wright SD, Ramos RA, Tobias PS, Ulevitch RJ, Mathison JC. CD14, a receptor for complexes of lipopolysaccharide (LPS) and LPS binding protein. Science. (1990) 249:1431-3. doi: 10.1126/science.1698311

107. Tapping RI, Tobias PS. Soluble CD14-mediated cellular responses to lipopolysaccharide. Chem Immunol. (2000) 74:10821. doi: $10.1159 / 000058751$ 
108. Jin L, Darveau RP. Soluble CD14 levels in gingival crevicular fluid of subjects with untreated adult periodontitis. J Periodontol. (2001) 72:63440. doi: 10.1902/jop.2001.72.5.634

109. Duncan L, Yoshioka M, Chandad F, Grenier D. Loss of lipopolysaccharide receptor CD14 from the surface of human macrophage-like cells mediated by Porphyromonas gingivalis outer membrane vesicles. Microb Pathog. (2004) 36:319-25. doi: 10.1016/j.micpath.2004.02.004

110. Isaza-Guzman DM, Aristizabal-Cardona D, Martinez-Pabon MC, Velasquez-Echeverri H, Tobon-Arroyave SI. Estimation of sCD14 levels in saliva obtained from patients with various periodontal conditions. Oral Dis. (2008) 14:450-6. doi: 10.1111/j.1601-0825.2007.01400.x

111. Diomede F, Zingariello M, Cavalcanti MFXB, Merciaro I, Pizzicannella J, De Isla $\mathrm{N}$, et al. MyD88/ERK/NFkB pathways and pro-inflammatory cytokines release in periodontal ligament stem cells stimulated by Porphyromonas gingivalis. Eur J Histochem. (2017) 61:2791. doi: 10.4081/ejh.2017.2791

112. Kukolj T, Trivanovic D, Djordjevic IO, Mojsilovic S, Krstic J, Obradovic H, et al. Lipopolysaccharide can modify differentiation and immunomodulatory potential of periodontal ligament stem cells via ERK1,2 signaling. J Cell Physiol. (2018) 233:447-62. doi: 10.1002/jcp.25904

113. Trubiani O, Ballerini P, Murmura G, Pizzicannella J, Giuliani P, Buccella S, et al. Toll-like receptor 4 expression, interleukin- $6,-8$ and Ccl-20 release, and NF-KB translocation in human periodontal ligament mesenchymal stem cells stimulated with LPS-P. gingivalis. Eur J Inflamm. (2012) 10:819. doi: 10.1177/1721727X1201000109

114. Kang SK, Park YD, Kang SI, Kim DK, Kang KL, Lee SY, et al. Role of resistin in the inflammatory response induced by nicotine plus lipopolysaccharide in human periodontal ligament cells in vitro. J Periodontal Res. (2015) 50:602-13. doi: $10.1111 /$ jre. 12240

115. Agarwal S, Chandra CS, Piesco NP, Langkamp HH, Bowen L, Baran C. Regulation of periodontal ligament cell functions by interleukin-1 $1 \beta$. Infect Immun. (1998) 66:932-7. doi: 10.1128/IAI.66.3.932-937.1998

116. Kang H, Lee MJ, Park SJ, Lee MS. Lipopolysaccharide-preconditioned periodontal ligament stem cells induce M1 polarization of macrophages through extracellular vesicles. Int J Mol Sci. (2018) 19:3843. doi: $10.3390 / \mathrm{ijms} 19123843$

117. Wang PL, Ohura K. Porphyromonas gingivalis lipopolysaccharide signaling in gingival fibroblasts-CD14 and toll-like receptors. Crit Rev Oral Biol Med. (2002) 13:132-42. doi: 10.1177/1544111302013 00204

118. Herath TD, Darveau RP, Seneviratne CJ, Wang CY, Wang Y, Jin L. Tetraand penta-acylated lipid A structures of Porphyromonas gingivalis LPS differentially activate TLR4-mediated NF-kappaB signal transduction cascade and immuno-inflammatory response in human gingival fibroblasts. PLoS ONE. (2013) 8:e58496. doi: 10.1371/journal.pone.00 58496

119. Behm C, Blufstein A, Abhari SY, Koch C, Gahn J, Schaffer C, et al. Response of human mesenchymal stromal cells from periodontal tissue to LPS depends on the purity but not on the LPS source. Mediators Inflamm. (2020) 2020:8704896. doi: 10.1155/2020/8704896

120. Bozkurt SB, Hakki SS, Hakki EE, Durak Y, Kantarci A. Porphyromonas gingivalis lipopolysaccharide induces a proinflammatory human gingival fibroblast phenotype. Inflammation. (2017) 40:144-53. doi: 10.1007/s10753-016-0463-7

121. Kang W, Hu Z, Ge S. Healthy and inflamed gingival fibroblasts differ in their inflammatory response to Porphyromonas gingivalis lipopolysaccharide. Inflammation. (2016) 39:1842-52. doi: 10.1007/s10753-016-0421-4

122. Souza PPC, Lundberg P, Lundgren I, Magalhaes FAC, Costa-Neto CM, Lerner UH. Activation of toll-like receptor 2 induces B1 and B2 kinin receptors in human gingival fibroblasts and in mouse gingiva. Sci Rep. (2019) 9:2973. doi: 10.1038/s41598-018-37777-z

123. Bender O, Weinberg E, Moses O, Nemcovsky CE, Weinreb M. Porphyromonas gingivalis lipopolysaccharide and glycated serum albumin increase the production of several pro-inflammatory molecules in human gingival fibroblasts via NFkappaB. Arch Oral Biol. (2020) 116:104766. doi: 10.1016/j.archoralbio.2020.104766

124. Sekot G, Posch G, Messner P, Matejka M, Rausch-Fan X, Andrukhov O, et al. Potential of the Tannerella forsythia S-layer to delay the immune response. $J$ Dent Res. (2011) 90:109-14. doi: 10.1177/0022034510384622
125. Basso FG, Soares DG, Pansani TN, Turrioni AP, Scheffel DL, de Souza Costa CA, et al. Effect of LPS treatment on the viability and chemokine synthesis by epithelial cells and gingival fibroblasts. Arch Oral Biol. (2015) 60:1117-21. doi: 10.1016/j.archoralbio.2015.04.010

126. Hosokawa Y, Hosokawa I, Ozaki K, Nakae H, Matsuo T. Increase of CCL20 expression by human gingival fibroblasts upon stimulation with cytokines and bacterial endotoxin. Clin Exp Immunol. (2005) 142:28591. doi: 10.1111/j.1365-2249.2005.02912.x

127. Lappin MJ, Brown V, Zaric SS, Lundy FT, Coulter WA, Irwin CR. Interferongamma stimulates CD14, TLR2 and TLR4 mRNA expression in gingival fibroblasts increasing responsiveness to bacterial challenge. Arch Oral Biol. (2016) 61:36-43. doi: 10.1016/j.archoralbio.2015.10.005

128. Wang D, Zhu NX, Qin M, Wang YY. Betamethasone suppresses the inflammatory response in LPS-stimulated dental pulp cells through inhibition of NF-kappaB. Arch Oral Biol. (2019) 98:156-63. doi: 10.1016/j.archoralbio.2018.11.022

129. Wang J, Dai J, Liu B, Gu S, Cheng L, Liang J. Porphyromonas gingivalis lipopolysaccharide activates canonical Wnt/beta-catenin and p38 MAPK signalling in stem cells from the apical papilla. Inflammation. (2013) 36:1393-402. doi: 10.1007/s10753-013-9679-y

130. Zhang J, Zhang Y, Lv H, Yu Q, Zhou Z, Zhu Q, et al. Human stem cells from the apical papilla response to bacterial lipopolysaccharide exposure and anti-inflammatory effects of nuclear factor I C. J Endod. (2013) 39:141622. doi: 10.1016/j.joen.2013.07.018

131. Chatzivasileiou K, Lux CA, Steinhoff G, Lang H. Dental follicle progenitor cells responses to Porphyromonas gingivalis LPS. J Cell Mol Med. (2013) 17:766-73. doi: $10.1111 / \mathrm{jcmm} .12058$

132. Hashimoto M, Asay Y, Ogawa T. Separation and structural analysis of lipoprotein in a lipopolysaccharide preparation from Porphyromonas gingivalis. Int Immunol. (2004) 16:1431-7. doi: 10.1093/intimm/dxh146

133. Hirschfeld M, Ma Y, Weis JH, Vogel SN, Weis JJ. Cutting edge: repurification of lipopolysaccharide eliminates signaling through both human and murine toll-like receptor 2. J Immunol. (2000) 165:61822. doi: 10.4049/jimmunol.165.2.618

134. Blufstein A, Behm C, Nguyen PQ, Rausch-Fan X, Andrukhov O. Human periodontal ligament cells exhibit no endotoxin tolerance upon stimulation with Porphyromonas gingivalis lipopolysaccharide. J Periodontal Res. (2018) 53:589-97. doi: 10.1111/jre.12549

135. Uehara A, Takada H. Functional TLRs and NODs in human gingival fibroblasts. J Dent Res. (2007) 86:249-54. doi: 10.1177/1544059107086 00310

136. Mahanonda R, Sa-Ard-Iam N, Montreekachon P, Pimkhaokham A, Yongvanichit K, Fukuda MM, et al. IL-8 and IDO expression by human gingival fibroblasts via TLRs. J Immunol. (2007) 178:11517. doi: 10.4049/jimmunol.178.2.1151

137. Sugawara S, Arakaki R, Rikiishi H, Takada H. Lipoteichoic acid acts as an antagonist and an agonist of lipopolysaccharide on human gingival fibroblasts and monocytes in a CD14-dependent manner. Infect Immun. (1999) 67:1623-32. doi: 10.1128/IAI.67.4.1623-1632.1999

138. Andrukhov O, Ertlschweiger S, Moritz A, Bantleon HP, Rausch-Fan X. Different effects of $P$. gingivalis LPS and E. coli LPS on the expression of interleukin-6 in human gingival fibroblasts. Acta Odontol Scand. (2014) 72:337-45. doi: 10.3109/00016357.2013.834535

139. Moonen CGJ, Karlis GD, Schoenmaker T, Forouzanfar T, Loos BG, de Vries TJ. T Cell proliferation is induced by chronically TLR2stimulated gingival fibroblasts or monocytes. Int J Mol Sci. (2019) 20:6134. doi: 10.3390/ijms20246134

140. Waterman RS, Tomchuck SL, Henkle SL, Betancourt AM. A new mesenchymal stem cell (MSC) paradigm: polarization into a proinflammatory MSC1 or an Immunosuppressive MSC2 phenotype. PLoS ONE. (2010) 5:e10088. doi: 10.1371/journal.pone.0010088

141. Liotta F, Angeli R, Cosmi L, Fili L, Manuelli C, Frosali F, et al. Toll-like receptors 3 and 4 are expressed by human bone marrowderived mesenchymal stem cells and can inhibit their T-cell modulatory activity by impairing Notch signaling. Stem Cells. (2008) 26:27989. doi: 10.1634/stemcells.2007-0454

142. Rashedi I, Gomez-Aristizabal A, Wang XH, Viswanathan S, Keating A. TLR3 or TLR4 activation enhances mesenchymal stromal cell-mediated 
treg induction via notch signaling. Stem Cells. (2017) 35:265-75. doi: 10.1002/stem.2485

143. Tomic S, Djokic J, Vasilijic S, Vucevic D, Todorovic V, Supic G, et al. Immunomodulatory properties of mesenchymal stem cells derived from dental pulp and dental follicle are susceptible to activation by toll-like receptor agonists. Stem Cells Dev. (2011) 20:695-708. doi: 10.1089/scd.2010.0145

144. King NJ, Thomas SR. Molecules in focus: indoleamine 2,3-dioxygenase. Int $J$ Biochem Cell Biol. (2007) 39:2167-72. doi: 10.1016/j.biocel.2007.01.004

145. Munn DH, Mellor AL. Indoleamine 2,3 dioxygenase and metabolic control of immune responses. Trends Immunol. (2013) 34:137-43. doi: 10.1016/j.it.2012.10.001

146. Moon JS, Cheong NR, Yang SY, Kim IS, Chung HJ, Jeong YW, et al. Lipopolysaccharide-induced indoleamine 2,3-dioxygenase expression in the periodontal ligament. J Periodontal Res. (2013) 48:733-9. doi: 10.1111/jre.12063

147. Andrukhov O, Hong JS, Andrukhova O, Blufstein A, Moritz A, Rausch-Fan $\mathrm{X}$. Response of human periodontal ligament stem cells to IFN-gamma and TLR-agonists. Sci Rep. (2017) 7:12856. doi: 10.1038/s41598-017-12480-7

148. Behm C, Blufstein A, Gahn J, Kubin B, Moritz A, Rausch-Fan X, et al. Continuing effect of cytokines and toll-like receptor agonists on indoleamine-2,3-dioxygenase-1 in human periodontal ligament stem/stromal cells. Cells. (2020) 9:2696. doi: 10.3390/cells9122696

149. Lee S, Zhang QZ, Karabucak B, Le AD. DPSCs from inflamed pulp modulate macrophage function via the TNF-alpha/IDO axis. J Dent Res. (2016) 95:1274-81. doi: 10.1177/0022034516657817

150. Mekhemar MK, Adam-Klages S, Kabelitz D, Dorfer CE, Fawzy ElSayed KM. TLR-induced immunomodulatory cytokine expression by human gingival stem/progenitor cells. Cell Immunol. (2018) 326:607. doi: $10.1016 /$ j.cellimm.2017.01.007

151. Nakashima M, Iohara K. Mobilized dental pulp stem cells for pulp regeneration: initiation of clinical trial. J Endod. (2014) 40(Suppl. 4):S2632. doi: 10.1016/j.joen.2014.01.020

152. Hernandez-Monjaraz B, Santiago-Osorio E, Ledesma-Martinez E, AguinigaSanchez I, Sosa-Hernandez NA, Mendoza-Nunez VM. Dental pulp mesenchymal stem cells as a treatment for periodontal disease in older adults. Stem Cells Int. (2020) 2020:8890873. doi: 10.1155/2020/8890873

153. Ferrarotti F, Romano F, Gamba MN, Quirico A, Giraudi M, Audagna M, et al. Human intrabony defect regeneration with micrografts containing dental pulp stem cells: a randomized controlled clinical trial. J Clin Periodontol. (2018) 45:841-50. doi: 10.1111/jcpe.12931

154. Fernandes TL, Cortez de SantAnna JP, Frisene I, Gazarini JP, Gomes Pinheiro CC, Gomoll AH, et al. Systematic review of human dental pulp stem cells for cartilage regeneration. Tissue Eng Part B Rev. (2020) 26:112. doi: 10.1089/ten.teb.2019.0140

155. Moshaverinia A, Chen C, Xu X, Akiyama K, Ansari S, Zadeh HH, et al. Bone regeneration potential of stem cells derived from periodontal ligament or gingival tissue sources encapsulated in RGD-modified alginate scaffold. Tissue Eng Part A. (2014) 20:611-21. doi: 10.1089/ten.TEA.2013. 0229

156. Zheng C, Chen J, Liu S, Jin Y. Stem cell-based bone and dental regeneration: a view of microenvironmental modulation. Int J Oral Sci. (2019) 11:23. doi: 10.1038/s41368-019-0060-3

157. Cooper LF, Ravindran S, Huang CC, Kang M. A role for exosomes in craniofacial tissue engineering and regeneration. Front Physiol. (2019) 10:1569. doi: 10.3389/fphys.2019.01569

158. Stanko P, Altanerova U, Jakubechova J, Repiska V, Altaner C. Dental mesenchymal stem/stromal cells and their exosomes. Stem Cells Int. (2018) 2018:8973613. doi: 10.1155/2018/8973613

Conflict of Interest: The author declares that the research was conducted in the absence of any commercial or financial relationships that could be construed as a potential conflict of interest.

Copyright $\odot 2021$ Andrukhov. This is an open-access article distributed under the terms of the Creative Commons Attribution License (CC BY). The use, distribution or reproduction in other forums is permitted, provided the original author $(s)$ and the copyright owner(s) are credited and that the original publication in this journal is cited, in accordance with accepted academic practice. No use, distribution or reproduction is permitted which does not comply with these terms. 